\title{
Population dynamic of Sesarma rectum (Crustacea, Brachyura, Sesarmidae) from a muddy flat under human impact, Paraty, Rio de Janeiro, Brazil
}

\author{
Stella Maris Januário da Silva, Gustavo Luis Hirose \& Maria Lucia Negreiros-Fransozo
}

NEBECC (Group of Studies on Crustacean Biology, Ecology and Culture), Departamento de Zoologia, Instituto de Biociências, UNESP, Distrito de Rubião Junior, 18618-000 Botucatu, SP, Brazil.

\begin{abstract}
A population of Sesarma rectum Randall, 1840 under the influence of human impact was studied. Monthly sampling (CPUE, two people during $30 \mathrm{~min}$ ) took place from August/2001 to July/2002 at an impacted muddy flat in Paraty city, State of Rio de Janeiro $\left(23^{\circ} 13^{\prime} \mathrm{S}, 44^{\circ} 42^{\circ} \mathrm{W}\right)$. At the laboratory, specimens were classified by sex and measured with a vernier caliper $(0.01 \mathrm{~mm})$. The size at the beginning of the sexual maturity was obtained by means of different techniques: in the case of males it was used the allometric procedure and the macroscopic analysis of gonads wile for females, the size of the smallest ovigerous female was also considered. The population structure was evaluated by means the analysis of the variations in the modes of the size frequency distribution. The fecundity was assessed using sub samples of the egg mass. For males, the macroscopic analyses of gonads revealed larger values of carapace width than those obtained with morphometric analysis. Males larger than $18.5 \mathrm{~mm}$ of carapace width can be considered as mature. For females, such size was $17.4 \mathrm{~mm} \mathrm{CW}$. Despite of the human impact in the habitat, the population presented to be stable, as indicated by a single mode on the size frequency distribution. The second mode that appeared in some months is probably related to the entrance of juveniles in the population. The sex ratio of this population is closely approximating to $1: 1$ until crabs reach a carapace width of about $28 \mathrm{~mm}$; after that, males outnumbered females. Comparing the fecundity of the present population with a previous study from Ubatuba, it can be verified a difference in the number of eggs. The fecundity of Paraty's population is significantly lower than the Ubatuba's population. This is probably related to the scarcity of food resource in Paraty, once no vascular plant can be found in that place. The continuity of reproductive processes and the juvenile recruitment suggest this species is able to live in the area with human impact. The ability to obtaining nutrients from different source of food is probably a feature that allows $S$. rectum to occupy such impacted ecosystem.
\end{abstract}

KEYWORDS. Sexual maturity, allometric growth, population structure, fecundity.

RESUMO. Dinâmica populacional de Sesarma rectum (Crustacea, Brachyura, Sesarmidae) de uma área lodosa impactada, Paraty, Rio de Janeiro, Brasil. Estudou-se uma população do caranguejo Sesarma rectum Randall, 1840 que está sob a influência direta do impacto humano. Coletas mensais (CPUE, duas pessoas durante $30 \mathrm{~min}$ ) foram realizadas de agosto de 2001 a julho de 2002 numa área lodosa, localizada na cidade de Paraty, Estado do Rio de Janeiro ( $23^{\circ} 13^{\prime} \mathrm{S}, 44^{\circ} 42^{\prime} \mathrm{W}$ ). No laboratório, os espécimes foram classificados quanto ao sexo e posteriormente medidos com um paquímetro $(0,01 \mathrm{~mm})$. O tamanho do início da maturidade sexual foi obtido por meio de diferentes técnicas: no caso dos machos, utilizaram-se técnicas alométrica e a análise macroscópica das gônadas, enquanto para as fêmeas, o tamanho da menor fêmea ovígera também foi considerado. A estrutura da população foi avaliada pela análise da variação das modas da distribuição de freqüência por classes de tamanho. A fecundidade foi obtida por meio de subamostragens das massas de ovos. Para os machos, a análise macroscópica das gônadas revelou valores da largura da carapaça maiores que os obtidos com as análises morfométricas. Machos maiores que $18,5 \mathrm{~mm}$ de largura da carapaça foram considerados maduros. Para as fêmeas, o tamanho da maturidade foi $17,4 \mathrm{~mm}$ de LC. Apesar do impacto humano sobre o ecossistema, a população apresenta-se estável, o que é indicado pela presença de uma única moda na distribuição de freqüência de tamanho. Uma segunda moda aparece somente em alguns meses e, provavelmente, está relacionada à entrada de juvenis na população. A razão sexual da população é próxima de 1:1 até os caranguejos alcançarem o tamanho em torno de $28 \mathrm{~mm}$ de LC. A seguir o número de machos ultrapassa o de fêmeas. Comparando a fecundidade da presente população com a estudada previamente em Ubatuba, verificaram-se diferenças no número de ovos. A fecundidade da população de Paraty foi significativamente menor do que a de Ubatuba. Isto provavelmente está relacionado à escassez de recursos alimentares em Paraty, uma vez que não se encontram plantas vasculares naquele local. O processo reprodutivo contínuo, como também o recrutamento juvenil sugere que a espécie está apta a viver nesta área mesmo sob impacto humano. A capacidade de obtenção de nutrientes a partir de diferentes tipos de alimentos é provavelmente uma característica que possibilita $S$. rectum ocupar um ecossistema impactado.

PALAVRAS-CHAVE. Maturidade sexual, crescimento alométrico, estrutura populacional, fecundidade.

Populations are characterized by dynamic properties which are, in fact, evolutionary answers to environmental changes. In this context, studies on population structures provide a static vision at certain point in time, due to birth, death and individual migrations (RicKLEFs, 1996). The most common way to characterize the structure of a certain population is through size classes' graphs or age frequency distributions, which provide an estimative of animal growth, period and intensity of juvenile recruitment as well as possible seasonal variations (PIANKA, 1974).

The proportion of males and females is also a feature that reflects the balance of a population. A proportion of 1:1 is expected (FISHER, 1930) once an individual progeny of each sex has an equal budget to be produced (WILSON \& PIANKA, 1963). After birth, a set of factors can affect this relationship and bias the occurrence of one sex (LeIGH, 1970).

Another event that can reveals the interaction of a population with its environment is the beginning of reproductive phase, which represents a critical event in the animals' life history. The estimative of morphological maturity can be based on the analyses of biometric 
relations (HuXley, 1950). An index that is also used to determine invertebrate reproductive phases is based on the observation of gonad maturation obtained by macroscopic observations of color, weight and shape of gonads (Giese \& PEARSE, 1974).

The gonad development is commonly related to reproductive effort, which is defined as the energy drove to reproduction (LÓPEZ-GRECO \& RODRIGUEZ, 1999), mainly to the egg production. SASTRY (1983) observed that egg number and its production periodicity are species specific factors that reflect the reproductive strategy of each species, and the fecundity analysis does not only estimate the egg number, but it also represents the rhythms in which eggs are being produced.

The grapsoid crabs can be found throughout tropical and warm temperate regions. Among the Superfamily Grapsoidea, the Genus Sesarma Say, 1817 is one of the commonest representatives in mangroves around the world; Sesarma rectum Randall, 1840 can be found through Occidental Atlantic (from Venezuela and Guyana till Brazil) (MELO, 1996). Their feeding activity on vascular plants buds alters the environment regeneration (JoNES, 1984) and influences the ecosystem dynamic by the exportation of particulate material and nutrients to adjacent estuarine areas (LeE, 1989; Michel et al., 1991; ROBERTSON, 1991).

The human activities, such as constructions of piers and/or residential developments for tourism purposes located on estuaries and neighboring shores have been changed drastically such environments, preventing the establishment of certain organisms. In this sense, studies on population dynamics represent important information for species conservation.

The purpose of this paper is to evaluate the dynamic of a population of the mangrove crab $S$. rectum living at an environment under influence of human impact.

\section{MATERIAL AND METHODS}

Study site and sampling technique. The studied site is a muddy flat situated at Paraty city, State of Rio de Janeiro, Brazil (23 $\left.3^{\circ} 3^{\prime} \mathrm{S}, 44^{\circ} 42^{\prime} \mathrm{W}\right)$. Such area was constituted by mangrove vegetation in the past. Nowadays, none mangle tree can be found and only grasses and small bushes are covering the area.

Monthly sampling (CPUE, two people during 30 $\mathrm{min}$ ) took place from August/2001 to July/2002. Specimens were obtained by digging the sediment near the burrows with a diver knife and catching each crab sighted. In the laboratory, specimens were identified according to secondary sexual characters (abdomen morphology and number of pleopods). A vernier caliper (precision of 0.01 $\mathrm{mm}$ ) was used to measure the carapace width $(\mathrm{CW})$ and length (CL), abdomen width (AW), gonopod length (GL), cheliped propodus length (PL) and height (PH).

Relative growth and sexual maturity. The differential growth of some body parts (dependent variables) in relation to carapace width (independent variable) was used as a tool to identify the size around which the transition between juvenile and adult phases took placed. All analyses were based on the function designed by HUXLEY (1950), which was later linearized $(\log y=\log a+$ $b \log x$ ). The constant "b", that expresses the analogy among variables was tested by a Student's $t$ test $(\alpha=0.05)$ (SOKAL \& RohlF, 1995) indicating isometry $(b=1)$, positive allometry $(b>1)$ or negative allometry $(b<1)$ (TeIsSIER, 1960; HARTNOLL, 1982). The similarity among slopes and intercepts for each relation of juvenile and adult was tested by a covariance analysis $(\alpha=0.05)$ (SOKAL $\&$ ROHLF, 1995).

The identification of immature and adult phases is not clear in some cases. In order to minimize the problems related for estimate the sexual maturity, the size around which the puberty molt of females occurs was accessed by three different procedures: the allometric technique using the softwares Mature I and II (SOMERTON, 1980a, b), the size of the smallest ovigerous females and the macroscopic determination of gonad development. For males, the allometry and the last techniques were used. The gonads of both sexes were classified into two stages: immature and mature. Immature males have filamentous and translucent gonads, while the mature ones have their gonads spiraled. For females, mature gonads occupy a large portion of cephalothoraxes space, with a predominance of red and purple colors, while immature gonads are smaller, transparent and inconspicuous. The macroscopic analyses of gonads indicated the size class where half of the individuals were mature $\left(\mathrm{CW}_{50 \%}\right)$.

Population structure. The median sizes of males and females were compared using a Mann-Whitney U Test $(\alpha=5 \%)$ (SOKAL \& RoHLF, 1995). The specimens were monthly distributed in size classes according to STURGES (1926). The size at onset sexual maturity was based on the smallest value obtained in the different procedures (allometric technique, smallest ovigerous females and the macroscopic analyses of gonads) above described. A Chisquare test for goodness of fit ( $\alpha=5 \%$ ) was performed to verify whether the sex ratio in the population departed significantly from 1:1 (SOKAL \& RoHLF, 1995), throughout the sampling period and size classes.

Reproductive period and fecundity. Egg masses in initial stage of development, recognized by egg completely filled with yolk as mentioned by NEGREIROS-FrANSOZO et al. (2004), were kept in alcohol 70\%. Those eggs that were still adhered to pleopods were immersed in a solution of 5-6\% sodium hypochlorite $(\mathrm{NaClO})$. After that, they were separated using a mechanical shaker. As this species bears a large amount of eggs, a subsampling, obtained by Motoda sampler, was counted. The counting was performed under stereomicroscope using a manual counter and then total number of eggs was calculated for the whole egg mass. A dispersion diagram was made for the relationship between egg number and the carapace width. These values were submitted to a regression analysis.

The annual proportion of ovigerous females in relation to non-ovigerous, was compared with a Goodman test $(\alpha=0.05)$ (CURI \& Moraes, 1981) that evaluates contrasts between binomial proportions. A possible correlation between the frequency of ovigerous females and the monthly temperature in the region (data obtained with the Centro de Pesquisa Meteorológica e Climáticas Aplicadas à Agricultura) was evaluated by means of a crosscorrelation (STATSOFT, 2001).

\section{RESULTS}

Relative growth and sexual maturity. Among all performed relationships, those that better indicated the onset of morphological maturity were CW vs. PL for males and CW vs. AW, for females (Tab. I). Males become 
morphologically mature when they reached around 14.7 $\mathrm{mm} \mathrm{CW}$. For females, the transitional phase (13.2 to 18.5 $\mathrm{mm}$ ) indicates a size range where it is possible to find mature and immature individuals (Fig. 1).

The macroscopic analyses of gonads indicated that the sexual maturity is attained at $18.5 \mathrm{~mm} \mathrm{CW}$ for males and $17.5 \mathrm{~mm} \mathrm{CW}$ for females; in these sizes, $50 \%$ of males and $50 \%$ of females bear mature gonads (Fig. 2).
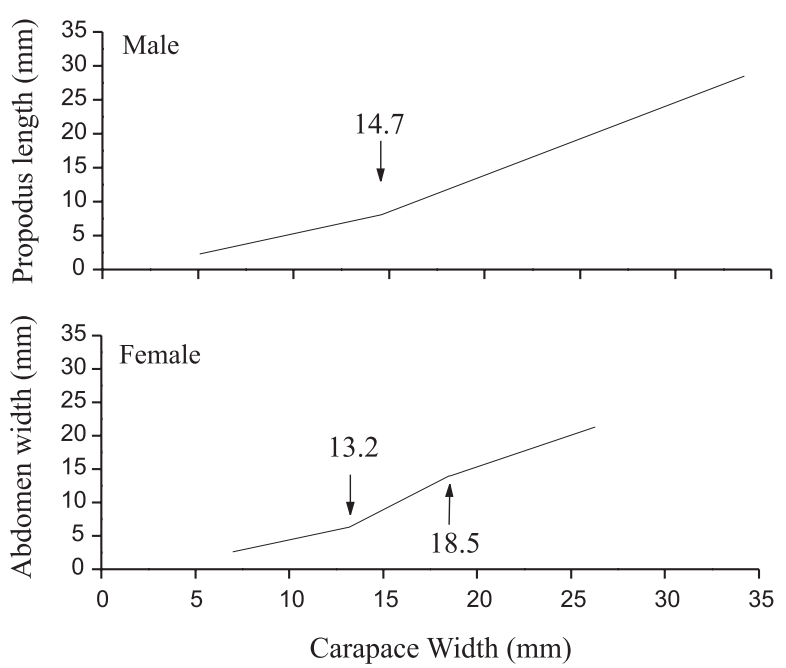

Fig. 1. Straight lines for juvenile and adult phases of Sesarma rectum Randall, 1840 from Paraty, State of Rio de Janeiro. Setae indicate the beginning of the morphological sexual maturity for males and the transitional phase for females.

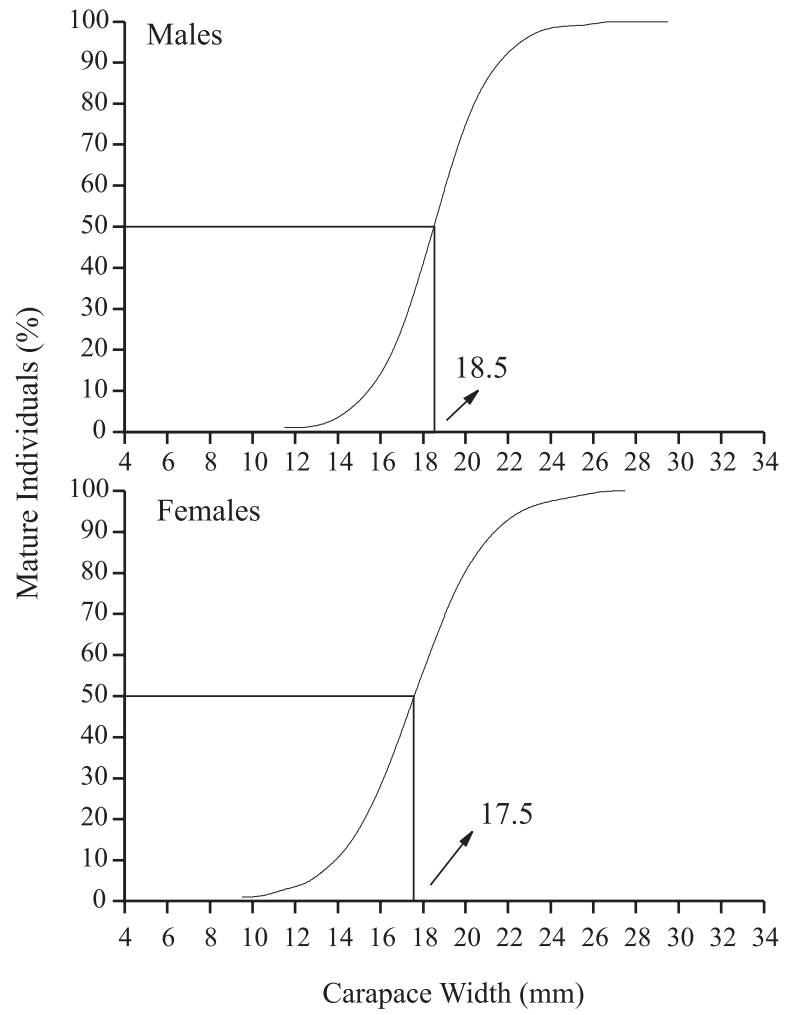

Fig. 2. Curves of maturity of Sesarma rectum Randall, 1840 from Paraty, State of Rio de Janeiro. Setae indicate the sizes where 50\% of males or females have mature gonads.

Table I. Results of regressions analyses obtained for the population of Sesarma rectum Randall, 1840 from Paraty, State of Rio de Janeiro. (AF, adult females; AM, adult males; AW, abdomen width; CL, carapace length; CW, carapace width; GL, gonopod length; JM, juvenile males; JF, juvenile females; N, number of crabs; PH, propodus height; PL, propodus length; TF, transitional females; + positive allometry; 0 , isometry; -, negative allometry).

\begin{tabular}{|c|c|c|c|c|c|c|c|c|c|c|}
\hline \multirow[t]{2}{*}{ Relationships } & \multirow[t]{2}{*}{ Sex } & \multirow[t]{2}{*}{$\mathrm{N}$} & \multirow[t]{2}{*}{ Intercept"a" } & \multirow[t]{2}{*}{ Slope"b" } & \multirow[t]{2}{*}{$r^{2}$} & \multirow[t]{2}{*}{$\mathrm{t}(\mathrm{b}=1)$} & \multirow[t]{2}{*}{$p$} & \multirow[t]{2}{*}{ Allometry } & \multicolumn{2}{|c|}{$\begin{array}{l}\text { Results of } \\
\text { Mature II }\end{array}$} \\
\hline & & & & & & & & & $\mathrm{F}$ value & Cut point \\
\hline \multirow[t]{5}{*}{$\overline{\mathrm{CW} v s . \mathrm{CL}}$} & $\mathrm{JM}$ & 47 & 0.150 & 1.658 & 0.639 & 3.547 & 0.000 & + & & \\
\hline & $\mathrm{AM}$ & 277 & 0.806 & 1.019 & 0.518 & 0.322 & 0.747 & 0 & & \\
\hline & $\mathrm{JF}$ & 31 & 1.061 & 0.898 & 0.891 & 1.733 & 0.093 & 0 & & \\
\hline & $\mathrm{TF}$ & 70 & 0.764 & 1.035 & 0.960 & 1.409 & 0.163 & 0 & & \\
\hline & $\mathrm{AF}$ & 166 & 0.905 & 0.980 & 0.905 & 0.807 & 0.420 & 0 & & \\
\hline \multirow[t]{5}{*}{ CWvs.AW } & $\mathrm{JM}$ & 34 & 0.337 & 1.012 & 0.827 & 0.153 & 0.879 & 0 & & \\
\hline & $\mathrm{AM}$ & 257 & 0.389 & 0.971 & 0.955 & 2.218 & 0.027 & - & & \\
\hline & $\mathrm{JF}$ & 28 & 0.173 & 1.389 & 0.939 & 34.623 & 0.000 & + & & \\
\hline & $\mathrm{TF}$ & 59 & 0.012 & 2.397 & 0.949 & 19.032 & 0.000 & + & 26.93 & $13.2 \mathrm{~mm}$ \\
\hline & $\mathrm{AF}$ & 130 & 0.384 & 1.229 & 0.964 & 0.656 & 0.513 & 0 & 114.88 & $18.5 \mathrm{~mm}$ \\
\hline \multirow[t]{5}{*}{ CWvs.PL } & $\mathrm{JM}$ & 106 & 0.327 & 1.198 & 0.963 & 9.00 & 0.000 & + & & \\
\hline & $\mathrm{AM}$ & 201 & 0.119 & 1.558 & 0.934 & 19.24 & 0.000 & + & 74.74 & $14.7 \mathrm{~mm}$ \\
\hline & $\mathrm{JF}$ & 36 & 0.311 & 1.196 & 0.911 & 3.074 & 0.004 & + & & \\
\hline & $\mathrm{TF}$ & 70 & 0.253 & 1.262 & 0.744 & 3.004 & 0.003 & + & & \\
\hline & $\mathrm{AF}$ & 138 & 0.217 & 1.312 & 0.828 & 6.114 & 0.000 & + & & \\
\hline \multirow[t]{5}{*}{ CWvs.PH } & $\mathrm{JM}$ & 47 & 0.131 & 1.287 & 0.756 & 2.638 & 0.011 & + & & \\
\hline & $\mathrm{AM}$ & 265 & 0.046 & 1.688 & 0.954 & 30.257 & 0.000 & + & & \\
\hline & $\mathrm{JF}$ & 35 & 0.134 & 1.241 & 0.790 & 2.170 & 0.037 & + & & \\
\hline & $\mathrm{TF}$ & 70 & 0.055 & 1.570 & 0.906 & 9.418 & 0.000 & + & & \\
\hline & $\mathrm{AF}$ & 146 & 0.089 & 1.404 & 0.868 & 8.925 & 0.000 & + & & \\
\hline \multirow[t]{2}{*}{ CWvs.GL } & $\mathrm{JM}$ & 44 & 0.027 & 1.987 & 0.776 & 5.99 & 0.000 & + & & \\
\hline & $\mathrm{AM}$ & 273 & 0.332 & 1.036 & 0.913 & 1.901 & 0.058 & 0 & & \\
\hline
\end{tabular}


Population structure. The specimens were monthly distributed into 14 size classes with amplitude $2 \mathrm{~mm} \mathrm{CW}$ and classified according to the following demographic categories: juvenile males, adult males, juvenile females, adult females and ovigerous females (Fig. 3).

The median size of adult males was greater than adult females $(\mathrm{p}=0.00)$, within which ovigerous ones were included. The sex of individuals smaller than $4.8 \mathrm{~mm} \mathrm{CW}$ could not be identified. Males smaller than $14.6 \mathrm{~mm}$ and females smaller than $13.1 \mathrm{~mm} \mathrm{CW}$ were considered as juvenile individuals (Tab. II).

Males and females showed differential dynamic in the replacement of size frequency modes throughout the year period. It is possible to observe an increase (adult males in April and May/2002) and a decrease (adult females in February, March and April) in the number of individuals in some size classes. Despite of the presence of juvenile crabs in 10 of 12 collection months, the juvenile recruitment was more intense in August and September/ 2001 as well as in June and July/2002. In these months a second mode appeared.

In a general way, the population sex ratio biased males $\left(1: 0.8 \chi^{2}=51.126\right)$. However, considering the whole year only in April and May/2002 the male's proportion was higher than females $\left(\chi^{2}=6.540\right.$ and $\chi^{2}=6.868$ respectively) (Fig. 4). The sex ratio in each size class revealed that males outnumbered females only in classes larger than $28.0 \mathrm{~mm} \mathrm{CW}\left(\chi^{2}=16.030 ; \chi^{2}=20\right.$ and $100 \%$ males respectively) (Fig. 5).

Reproductive period and fecundity. A total of 73 ovigerous females were obtained throughout the year. Among them, 44 females which sizes varied from 17.4 to $26.4 \mathrm{~mm} \mathrm{CW}$, bore eggs in early developmental stages, and they were used to estimate the mean fecundity range from 3024 to 12784 (mean of $7840.6 \pm 2619.121$ eggs per female) (Fig. 6). Ovigerous females' frequency was, in general, continuous throughout the year, with peaks of reproductive activity in November, December/2001 and January/2002. In October/2001 however, no ovigerous was registered (Fig. 7).

The mean temperature of Paraty region during the sampling period was $27.6^{\circ} \mathrm{C}$, not presenting a greater variation throughout the year (Fig. 8). The crosscorrelation analysis indicated a time lag of two month between the number of ovigerous female's and the monthly air temperature ( $\mathrm{p}=0.00$ and $\mathrm{R}=0.68)$ (Fig. 9).
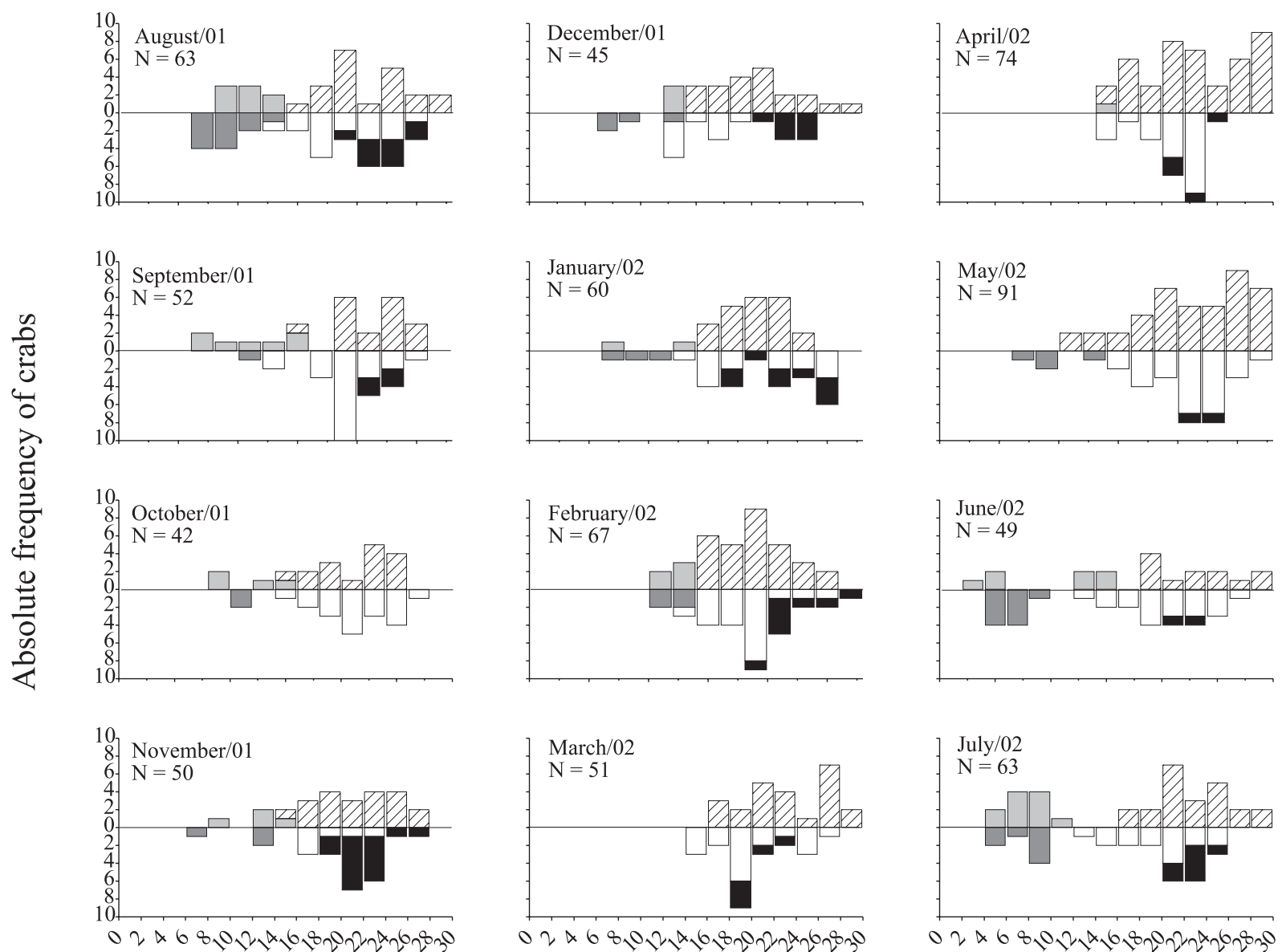

Carapace Width (mm)

Adult males $\square$ Juvenile males $\square$ Adult females $\square$ Juvenile females $\square$ Ovigerous females

Fig. 3. Size frequency distribution of Sesarma rectum Randall, 1840 from Paraty, State of Rio de Janeiro between August of 2001 and July of 2002 . 


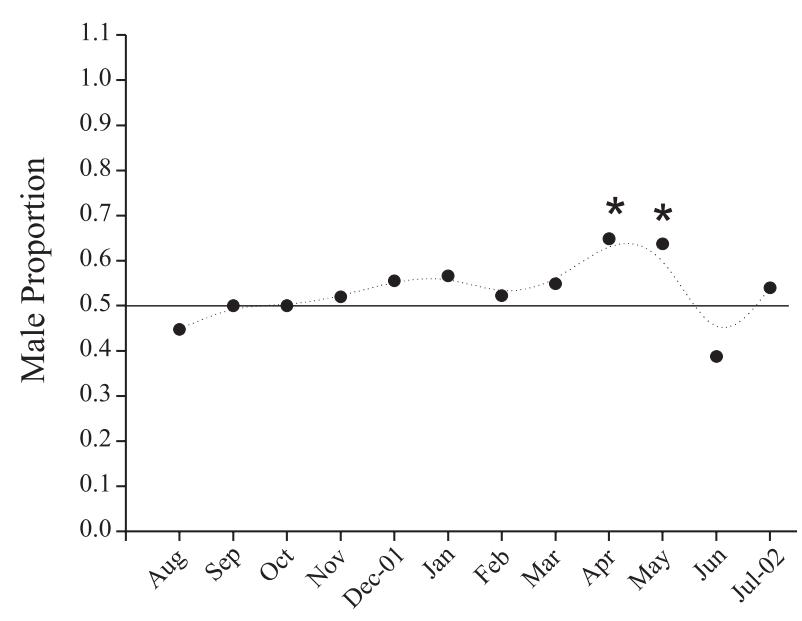

Months

Fig. 4. Oscillation of the male proportion of Sesarma rectum Randall, 1840 in Paraty, State of Rio de Janeiro between August of 2001 and July of 2002 . The * indicates statistical significant difference $\left(\chi^{2}, \mathrm{p}<0.05\right)$

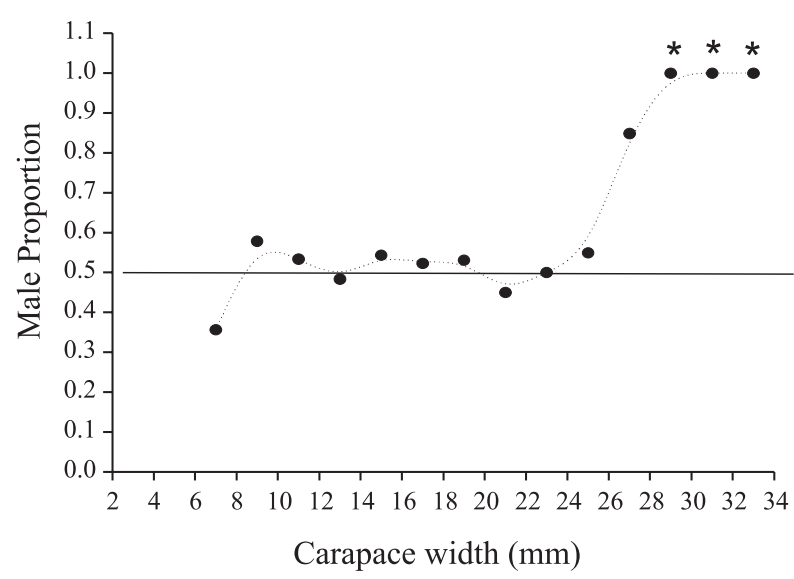

Fig. 5. Proportion of males of Sesarma rectum Randall, 1840 in Paraty, State of Rio de Janeiro throughout size classes. The * indicates statistical significant difference $\left(\chi^{2}, \mathrm{p}<0.05\right)$.

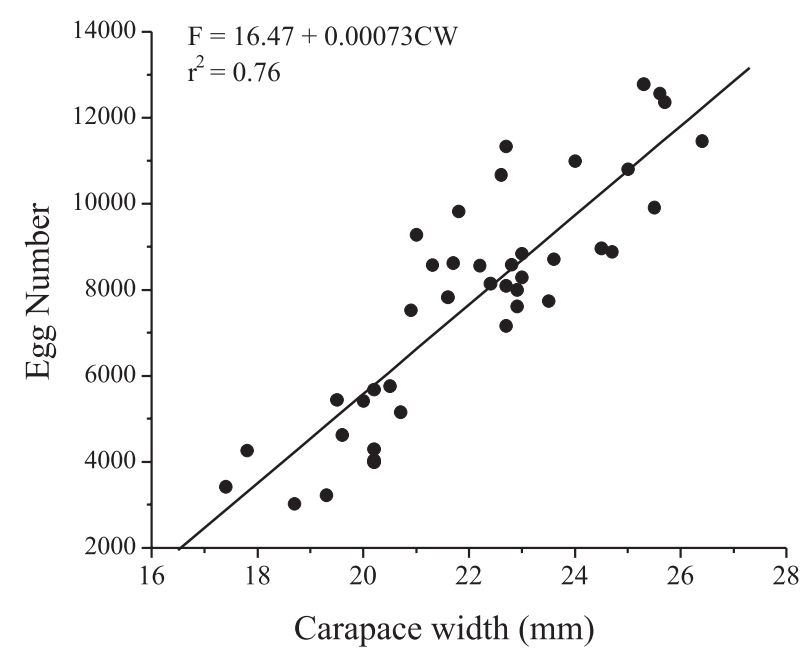

Fig. 6. Relationship between carapace width and egg number for Sesarma rectum Randall, 1840 from Paraty River, State of Rio de Janeiro. (CW, carapace width).
Table II. Descriptive statistics for each demographic category of Sesarma rectum Randall, 1840 from Paraty, State of Rio de Janeiro. (AF, adult females; AM, adult males; CW, carapace width; JM, juvenile males; JF, juvenile female; $\mathrm{N}$, number of crabs; OF, ovigerous females; sd, standard deviation. * Statistical difference between $\mathrm{AM}$ and $\mathrm{AF}, \mathrm{p}=0.000162$ ).

\begin{tabular}{lrccc}
\hline $\begin{array}{l}\text { Demographic } \\
\text { category }\end{array}$ & N & Min.-max. (CW) & Median & Mean \pm sd \\
\hline JM & 61 & $4.8-14.6$ & 10.6 & $10.5 \pm 2.9$ \\
AM & 322 & $14.7-33.3$ & $21.9^{*}$ & $22.2 \pm 4.3$ \\
JF & 47 & $4.9-13.1$ & 8.2 & $8.8 \pm 2.3$ \\
AF & 207 & $13.3-27.3$ & $19.6^{*}$ & $19.6 \pm 3.3$ \\
OF & 73 & $17.4-27.3$ & 22.2 & $22.1 \pm 2.1$ \\
\hline
\end{tabular}

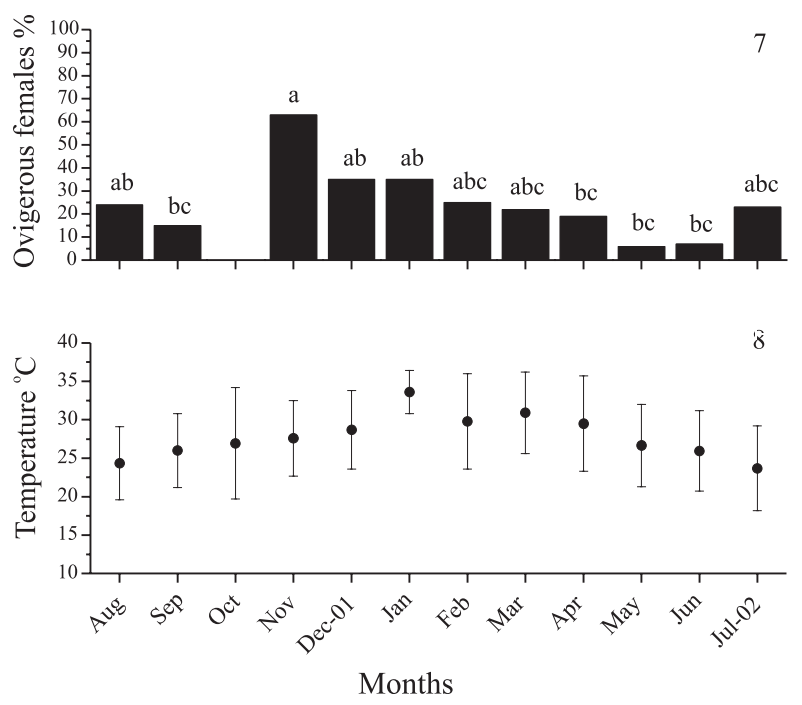

Figs. 7, 8. 7, proportion of ovigerous females of Sesarma rectum Randall, 1840 throughout the sampling period. Bars with at least one same letter in common did not differ statistically $(\alpha=0.05)$; 8 , means of temperature in Paraty, State of Rio de Janeiro between August of 2001 and July of 2002, the whisker represent the maximum and minimum values of temperature of month.

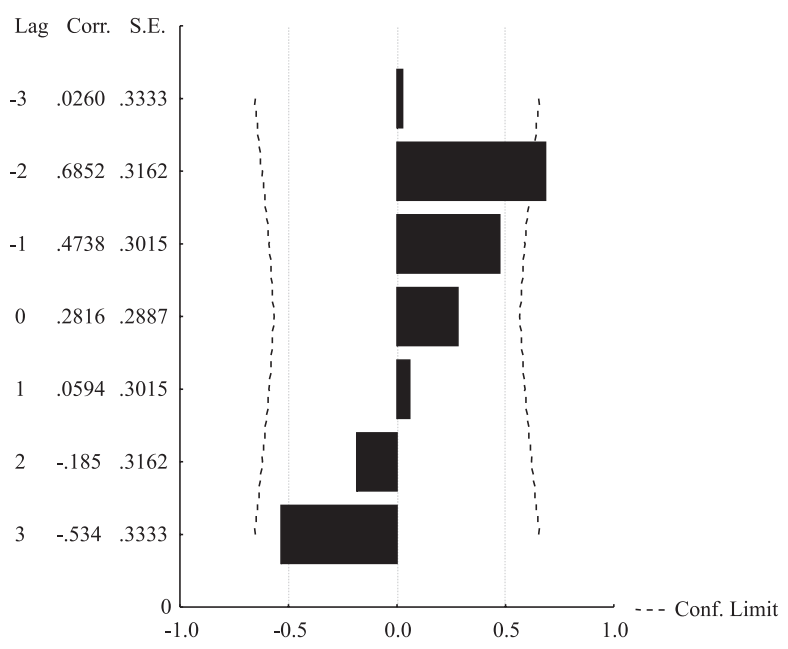

Fig. 9. Crosscorrelation analysis between ovigerous females' frequency and monthly air temperature of the Paraty region, State of Rio de Janeiro. 


\section{DISCUSSION}

In general, males of crab species are considered morphologically mature once they are able to retain females during pre and post copulatory guarding and to transfer successfully sperm to females, while females reach maturity when they are able to mate and spawn (HARTNOLL, 1969). However, maturity must be considered as a long process rather than a precise moment (LuPPI $e t$ al. 2004). In this paper different procedures were utilized to evaluate the beginning of sexual maturity in order to estimate it more accurately; as morphometric, gonadal and functional maturities are not always synchronized and each step may be achieved at a different molt (LóPEZGreco \& Rodriguez, 1999). Thus, it is suggested a size class in which crabs are probably mature.

The analyses of allometric growth of chelipeds indicate a resemblance between males and females, suggesting that these appendages display a similar function in both sexes. This supposition is supported by similar morphometric data obtained by other authors e.g. Сово \& Fransozo (1998) with Goniopsis cruentata (Latreille, 1803) and SAntos et al. (1995) with Portunus spinimanus Latreille, 1819. Thus, in these cases, the allometry of chelipeds is not the best way to estimate the sexual maturity size. For this reason, the macroscopic analyses of gonads seemed to be the more precise procedure to know the size of the males' sexual maturity: $18.5 \mathrm{~mm} \mathrm{CW}$ for $S$. rectum.

Differently from males, the analyses of females allometric growth revealed a phase in which large immature and small mature females can be found. NegreirosFransozo et al. (2003) studying a population of the fiddler crab Uca thayeri Rathbun, 1900 found out the same pattern of three growth-straight lines and referred the intermediate phase as "transitional" one. The macroscopic analyses of gonads indicated that the size where $50 \%$ of females had mature gonads is very close to the size of the smallest ovigerous female. In the same way that occurs for males, it is not possible to be sure about the exact size when females became sexually mature, but it is suggested to be $17.4 \mathrm{~mm}$ of $\mathrm{CW}$.

Comparing the sizes at sexual maturity for female obtained in this study and that by Leme (2005) with a population of $S$. rectum from Ubatuba, SP, it can be verified a very close value for both populations. The values obtained by LEME (2005) for morphologic sexual maturity, gonad sexual maturity and smallest ovigerous females were 15 to $21 \mathrm{~mm}, 17.42 \mathrm{~mm}$ and $17.4 \mathrm{~mm}$ of CW. Although the drastic perturbation in the estuarine area in Paraty, RJ by removing all mangle trees, apparently, the grasses area inhabited by S. rectum and Armases rubripes (Rathbun, 1897) (another sesarmid crab) was not affected. Thus, this human destructive action does not seem to interfere in the process that drives the sexual maturity size of $S$. rectum, as its microhabitat was not changed.

The population frequency distribution throughout most of the months was, in general, represented by a single mode, for males and females, which can indicate the stability of such population in the area (HARTNOLL \& BRYANT, 1990), although the above human impact. Some authors (Conde \& Díaz, 1989; Negreiros-Fransozo, 2002) studying other crab populations observed that some sesarmid species are able to adapt in cases of adverse conditions, due to their phenotypic plasticity.

The appearance of a second mode indicated a higher juvenile recruitment; however juveniles coming up to the population throughout the whole year corroborates the hypotheses of stability of populations in the study area. Differences in monthly size frequency distributions are typically found in species that produce several clutches per individual (Rabalais, 1991; SpivaK et al., 1991; MOUTON \& FELDER, 1995).

The deviation in the sex ratio from 1:1 in the upper size classes observed in $S$. rectum is considered as "standard" by WeNNER (1972). JOHNSON (2003) suggests many factors (differential growth rate, differential production of gametes, differential mortality between sexes) that can influence the balance of sex ratio, but in the case of present study, it seems more plausible that it is dependent on the size range of each sex. Shanholtzer (1973) apud Johnson (2003) has observed the same patterns for Uca pugnax (Smith, 1870), in other words, with increasing carapace width the sex ratio showed an increasing bias males, suggesting that the deviant sex ratio among adult is acquired. Many authors have been related the differential growth of males and females to the characteristic reproductive strategies that both sex as have developed as CONDE \& DíAZ (1989) with Aratus pisonii (H. Milne Edwards, 1837), Haefner \& SPAARGAREN (1993) with Crangon crangon L. and LupPI et al. (2004) with Chasmagnathus granulatus Dana, 1851.

In the population of $S$. rectum studied here the reproductive strategies apparently carry out an influence in the sex ratio beginning after de sexual maturity, presenting a significantly deviation for males in the last classes. The energy allocation to reproduction should be proportionally stronger in females, because more energy is needed for the production of oocytes than spermatocytes, and this way, females can cease or diminish their somatic growth during the period of egg's incubation (ALUNNOBRUSCIA \& SAINTE-MARIE, 1998). Slower growth can result from a reduced energy intake due to restrictions on feeding, and limitation on feeding occurs during several reproductive activities (HARTNOLL, 2006).

The fecundity of the studied population and that obtained by LEME (2004) for $S$. rectum in the mangrove of Comprido River, Ubatuba, SP ( $23^{\circ} 29^{\prime}$ S and $\left.45^{\circ} 09^{\prime} \mathrm{W}\right)$ were compared by a covariance analysis (ZAR, 1996): straight lines were produced by the fecundities of two populations. The results showed that fecundity of $S$. rectum differs between sites (Ancova: $\mathrm{A} 1 \neq \mathrm{A} 2 ; \mathrm{p}=0.00$ ). Despite of the similar size at sexual maturity in these populations, the fecundity of population from Ubatuba shows higher values than that from Paraty's population. This difference can be due to the availability of food resource necessary for processes like growth and reproduction. According to LEME (2004), the mangrove from Ubatuba supplies the species with food and shelters; the habitat seems to be physically heterogeneous providing a variety of microhabitats. It shows vegetation structure composed by Avicennia shaueriana Stapf \& Leechman ex Moldenke, Rhizophora mangle L. and Laguncularia racemosa L., Hibiscus sp. L. and Spartina sp. Loiseleur. 
On the other hand, the mangrove in Paraty has been reduced by the city progress. All trees had been cut in order to construct a car parking but, while such construction is not conclude, the grass area has been used as pasture.

The studied site has no vascular vegetation as food source and refuges are not available for all crabs in the area. Thus, females must invest on reproduction as soon as they can, despite of the production of small batch of eggs. Probably, this process is possible due to the species plasticity, as occurs in Aratus pisonii, studied by NEGREIROS-FrANSOZO (2002).

The eggs periodicity is also influenced by environmental conditions. LEME (2004) observed a seasonal reproductive activity for $S$. rectum from Ubatuba. However, when the low number of ovigerous females obtained is considered, it is quite dangerous to confirm if the process is really discontinuous, mainly, taking into account the cryptic behavior shown by the species.

The continuous presence of ovigerous females as well as the juvenile recruitment throughout the year may reveal the strategy developed by the species to maintain itself in the area, despite the environmental impact. The continuity of such processes may be related to the annual air temperature which means oscillates around $27^{\circ} \mathrm{C}$. As noted by GIESE (1959), for marine and coastal animal species the temperature is probably the most important environmental factor which affects the reproductive cycle, mainly because the larval abundance seems to have a positive relation with physical agents (SPRUNG, 2001; CRABE, 2003). In this sense, seasonal fluctuations in temperature as well as in salinity may be responsible for the different annual patters of larval hatching of some species (SANDOZ \& Rogers, 1944; HsuEH, 1991).

Although such continuity in reproduction, the size frequency distribution revealed a period when the reproduction seems to be more intense, the summer, when percentage of ovigerous females is high. The analysis of the crosscorrelation showed the existence of a time lag of two month between the frequency of ovigerous females and the temperature, which means that an increase in the number of ovigerous females precede an increase in the air temperature by two month. Such delay must be related to the period of larval development. Probably the time when larval pool is returning into to the adult population coincides with the peak in the air temperature.

Seiple \& Salmon (1987) studying life-history contrasts of two sesarmid species, Sesarma cinereum (Bosc) and Sesarma reticulatum (Say), determined a period of, approximately, 14 days of egg incubation for both species. Taking into account the species $S$. rectum presents a similar embryonic period and a planktonic developmental period of approximately 20 days (FRANSOZO \& NegreIros-Fransozo, 1986) it is reasonable to think the delayed correlation found between the number of ovigerous females and the temperature guaranty that megalopae and recent recruits are being benefit to ingress into the population when local conditions are more favorable.

Considering that human activities are responsible for the most part of ecosystem degradations it is extremely important to improve sustainable development aiming the restoration of impacted ecosystems and the return of characteristic biodiversity of each habitat (EYsinK et al., 1997). As showed in this paper, the lowered fecundity in the $S$. rectum population from Paraty, can be considered a first step to local disappearing of this species.

Acknowledgements. To FAPESP for the financial support during field works (\# 94/4878-8 and \# 98/3134-6) and NEBECC colleagues who helped in the laboratory analysis. The samplings were accomplished according to state and federal laws related with wild animals.

\section{REFERENCES}

Alunno-Bruscia, M. B. \& Sainte-Marie, B. 1998. Abdomen allometry, ovary development and growth of female snow crab, Chionoecetes opilio (Brachyura, Majidae), in the northwestern Gulf of St. Lawrence. Canadian Journal Fishery and Aquatic Science 55:459-477.

Cobo, V. J. \& Fransozo, A. F. 1998. Relative growth of Goniopsis cruentata (Crustacea, Brachyura, Grapsidae), on the Ubatuba region, São Paulo, Brazil. Iheringia, Série Zoologia, 84:21-28.

Conde, J. E. \& DíAz, H. 1989. The mangrove tree crab Aratus pisonii in a tropical estuarine coastal lagoon. Estuarine Coastal and Shelf Science 28:639-650.

Curi, P. R. \& Moraes, R. V. 1981. Associação homogeneidade e contrastes entre proporções em tabelas contendo distribuições multinomiais. Ciência e Cultura 33:712-722.

Eysink, G. G. J.; Bacilieri, S.; Bernardo, M. P. S. L.; Silva, L. S.; Siqueira, M. C.; Summa, D.; Ackar, S. M. \& Vigar, N. D. 1997. Recuperação de manguezais degradados através do uso de propágulos de Rhizophora mangle acondicionados em estufa. In: Reunião Anual do Instituto Biológico, São Paulo, 64: $1-95$.

FISHER, R. A. 1930. The genetical theory of natural selection. Oxford, Claredon. 291p.

Fransozo, A. \& Negreiros-Fransozo, M. L. 1986. Influência da salinidade no desenvolvimento larval de Eriphia gonagra (Frabricius, 1781) e Sesarma (Holometopus) rectum Randall, 1840 (Crustacea, Decapoda), em laboratório. Revista Brasileira de Biologia 46(2):439-446.

Giese, A. C. 1959. Comparative physiology. Annual reproductive cycles of marine invertebrates. Annual Reviews of Physiology 21:547-576.

Giese, A. C. \& Pearse, J. S. 1974. General principals. In: Giese, A. C. \& Pearse, J. S. eds. Reproduction of marine invertebrates. Acoelomate and pseudocoelomate metazoans. New York, Academic. p.1-49.

Grabe, S. A. 2003. Seasonal periodicity of decapod larvae and population dynamics of selected taxa in New Hampshire (USA) coastal waters. Journal of Plankton Research 4(25):417-428.

Haefner, P. A. JR. \& SpaArgaren, D. H. 1993. Interaction of ovary and hepatopancreas during the reproductive cycle of Crangon crangon (L.) weight and volume relationship. Journal of Crustacean Biology 13:523-531.

Hartnoll, R. G. 1969. Mating in Brachyura. Crustaceana 16: $161-181$.

1982. Growth. In: Bliss, D. E. ed. The Biology of Crustacea: embryology, morphology and genetics. New York, Academic, v.2, p.111-196.

2006. Reproductive investment in Brachyura. Hydrobiologia 557:31-40.

Hartnoll, R. G. \& Bryant, A. D. 1990. Size-frequency distribution in decapod Crustacea - The quick, the dead, and the cast-offs. Journal of Crustacean Biology 10(1):14-19.

Hsueh, PAn-Wen. 1991. Seasonal occurrence and abundance of Brachyuran larvae in a coastal embayment of central California. Journal of Crustacean Biology 11(4):546-552.

HuXley, J. S. 1950. Relative growth and form transformation. Proceedings of the Royal Society of London 137(B):465-469.

Johnson, P. T. J. 2003. Biased sex ratios in fiddler crabs (Brachyura, 
Ocypodidae): a review and evaluation of the influence of sampling method, size class and sex-specific mortality. Crustaceana 76(5):559-580.

Jones, D. A. 1984. Crabs of the mangal ecosystem. In: Por, F. D. \& Dor, I. eds. Hidrobiology of the mangal. Boston, W. Junk. p.89-109.

LEE, S. Y. 1989. The importance of sesarminae crabs Chiromanthes spp. and inundation frequency on mangrove [Kandelia candal (L) Druce] leaf litter turnover in a Hong Kong tidal shrimp pond. Journal of Experimental Marine Biology and Ecology 131:22-43.

Leigh, E. G. 1970. Sex-ratio and different mortality between sexes. American Naturalist 104:205-210.

Leme, M. H. A. 2004. Fecundity and fertility of the mangrove crab Sesarma rectum Randall, 1840 (Grapsoidea) from Ubatuba, São Paulo, Brazil. Nauplius 12(1):39-44.

. 2005. Size at sexual maturity of female crabs Sesarma rectum Randall (Crustacea, Brachyura) and ontogenetic variations in the abdomen relative growth. Revista Brasileira de Zoologia 22(2):433-437.

López-Greco, L. \& Rodríguez, E. 1999. Size at the onset of sexual maturity in Chasmagnathus granulata Dana 1851 (Grapsidae, Sesarminae): a critical overall view about the usual criteria for its determination. In: Scharan, F. R. \& Vaupel Klein, J. C. von. eds. Crustacean and the biodiversity crisis. Leiden, Brill. p.675-689.

Luppi, T. A.; Spivak, E. D.; BAs, C. C. \& Anger, K. 2004. Molt and growth of an estuarine crab, Chasmagnathus granulatus (Brachyura: Varunidae), in Mar Chiquita coastal lagoon, Argentina. Journal of Applied Icthyology 20:333-344.

Melo, G. A. S. 1996. Manual de identificação dos Brachyura (caranguejos e siris) do litoral brasileiro. São Paulo, Plêiade. 603p.

Micheli, F.; Gherardi, F. \& Vaninni, M. 1991. Feeding and burrowing ecology of two East African mangrove crabs. Marine Biology 111:247-25.

Mouton, E. C. \& Felder, D. L. 1995. Reproduction of the fiddler crabs Uca longisignalis and Uca spinicarpa in a Gulf of Mexico salt marsh. Estuaries 19:51-61.

Negreiros-Fransozo, M. L. 2002. Size variation in the grapsid crab Aratus pisonii (H. Milne-Edwards, 1837) among populations from different subtropical mangroves. In: EscoBAR-BRIONES, E. \& Alvarez, F. eds. Modern approaches to the study of Crustacea. New York, Kluwer Academic. p.183-188.

Negreiros-Fransozo, M. L.; Colpo, K. D. \& Costa, T. M. 2003. Allometric growth in the fiddler crab Uca thayeri (Brachyura, Ocypodidae) from a subtropical mangrove. Journal of Crustacean Biology 23(2):273-279.

Negreiros-Fransozo, M. L.; Guimarães F. J. \& Colpo, K. D. 2004. Comparison of the embryonic phases for fecundity estimation in two semi terrestrial crab species (Decapoda: Brachyura) from subtropical mangroves. Acta Ambiental Catarinense 3(1):33-40.

Pianka, E. R. 1974. Evolutionary Ecology. New York, Harper \& Row. 356 p.

Rabalais, N. N. 1991. Egg production in crabs with abbreviated development. Crustacean Issues 12:217-234.

Ricklefs, R. 1996. A economia da natureza. Rio de Janeiro, Guanabara Koogan. 3ed. 470p.

Robertson, A. I. 1991. Plant-animal interactions and the structure and function of mangrove forest ecosystems. Australian Journal of Ecology 16:433-443.

Santos, S.; Negreiros-Fransozo, M. L. \& Fransozo, A. 1995. Morphometric relationships and maturation in Portunus spinimanus Latreille, 1819 (Crustacea, Brachyura, Portunidae). Revista Brasileira de Biologia 55(4):545-553.

SASTRY, A. N. 1983. Ecological aspects of reproduction. 179-270 In: Vernberg, F. J. \& Vernberg, W. B. eds. The Biology of Crustacea. Behavior and Ecology. New York, Academic Press. v.7. p.179-255.

Seiple, W. H. \& Salmon, M. 1987. Reproductive, growth and lifehistory contrasts between two species of grapsid crabs, Sesarma cinereum and $S$. reticulatum. Marine Biology 94:1-6.

Sokal, R. R. \& Rohlf, F. J. 1995. Biometry. New York, H. Freeman. $887 \mathrm{p}$.

Somerton, D. 1980a. A computer technique for estimating the size of sexual maturity in crabs. Canadian Journal of Fisheries and Aquatic Sciences 37:1488-1494. 1980b. The size at sexual maturity of the blue king crab, Paralithodes platypus, in Alaska. Fishery Bulletin 81:621-628.

Spivak, E. D.; Gavio, M. A. \& Navarro, C. E. 1991. Life history and structure of the world's southernmost Uca population: Uca uruguayensis (Crustacea, Brachyura) in Mar Chiquita lagoon (Argentina). Bulletin of Marine Science 48(3):679-688.

Sprung, M. 2001. Larval abundance and recruitment of Carnicus maenas L. close to its southern geographic limit: a case of match and mismatch. Hydrobiologia 449:153-158.

StatSoft. 2001. Statistica: data analysis software system, version 6.0. Tulsa, StatSoft, Inc.

Sturges, H. A. 1926. The choice of a class interval. Journal of the American Statistical Association 21:65-66.

Teissier, G. 1960. Relative growth. In: Watermann, T. H. ed. The physiology of Crustacea. New York, Academic Press. v.1, p. $537-560$.

Wenner, A. M. 1972. Sex-ratio as a function of size in marine Crustacea. American Naturalist 106:321-350.

Wilson, M. F. \& Pianka, E. R. 1963. Sexual selection sex ratio, and mating system. American Naturalist 97:405-407.

ZAR, J. H. 1996. Biostatistical analysis. New Jersey, Prentice Hall. 662p

Recebido em novembro de 2005. Aceito em novembro de 2006. ISSN 0073-4721

Artigo disponível em: www.scielo.br/isz 